STUDI

FRANCESI

\section{Studi Francesi}

Rivista quadrimestrale fondata da Franco Simone

142 (XLVIII | I) | 2004

Varia - fasc. I - gannio-aprile 2004

\title{
Ana Pairet, «Les mutacions des fables». Figures de la métamorphose dans la littérature française du Moyen Age
}

\section{G. Matteo Roccati}

\section{(2) OpenEdition}

Journals

Édition électronique

URL : https://journals.openedition.org/studifrancesi/40252

DOI : 10.4000/studifrancesi.40252

ISSN : 2421-5856

Éditeur

Rosenberg \& Sellier

Édition imprimée

Date de publication : 1 juillet 2004

Pagination : 155

ISSN : 0039-2944

\section{Référence électronique}

G. Matteo Roccati, « Ana Pairet, «Les mutacions des fables». Figures de la métamorphose dans la littérature française du Moyen Age », Studi Francesi [En ligne], 142 (XLVIII | I) | 2004, mis en ligne le 30 novembre 2015, consulté le 09 septembre 2021. URL : http://journals.openedition.org/studifrancesi/ 40252 ; DOI : https://doi.org/10.4000/studifrancesi.40252

Ce document a été généré automatiquement le 9 septembre 2021.

\section{cc) (†) $\odot$}

Studi Francesi è distribuita con Licenza Creative Commons Attribuzione - Non commerciale - Non opere derivate 4.0 Internazionale. 


\title{
Ana Pairet, «Les mutacions des fables». Figures de la métamorphose dans la littérature française du Moyen Age
}

\author{
G. Matteo Roccati
}

\section{RÉFÉRENCE}

ANA PAIRET, «Les mutacions des fables». Figures de la métamorphose dans la littérature française du Moyen Age, Paris, Honoré Champion Editeur («Essais sur le Moyen Age», 26), 2002; pp. 198.

1 Le livre entend examiner 1a métamorphose dans ses «usages poétiques et rhétoriques» (p. 16). Le premier chapitre est consacré au vocabulaire de 1a mutacion (mutare, forma et figura, etc.), à 1a notion de transformation dans 1a pensée du Moyen Age (entre miracle et merveille) et aux réécritures ovidiennes du XII siècle. Les chapitres suivants portent sur la littérature courtoise (II), l'Ovide moralisé (III), enfin (IV) sur trois œuvres de 1a fin du XIV et du début du XV $\mathrm{XV}^{\mathrm{e}}$ siècle ayant trait à 1'histoire contemporaine: le Voyage en Béarn de Jean Froissart, le Roman de Mélusine de Jean d'Arras et le Livre de la mutacion de Fortune de Christine de Pizan. Bibliographie (pp. 171-184), index nominum (pp. 185-190) et index rerum (pp. 191-193) terminent le volume. 